\title{
Reduction of Hypercholesterolemia and Proteinuria in Nephritic Rats by Low-Meat-Protein Diets
}

\author{
K. Yagasaki, K. Ebara, K. Fujisawa, M. KaWASAKi, \\ Y. MiURA, and R. FUnABIKI \\ Department of Applied Biological Science, Tokyo Noko University, \\ Fuchu, Tokyo 183, Japan
}

(Received July 12, 1994)

Summary The effects of low-meat-protein diets on hypercholesterolemia and proteinuria were studied in rats with nephrotoxic serum nephritis. After an injection of nephrotoxic serum, rats were given either a $20 \%$ meat-protein diet $(20 \mathrm{M})$, an $8.5 \%$-meat-protein diet $(8.5 \mathrm{M})$, or a valine(0.05\%)-supplemented $8.5 \%$-meat-protein diet (8.5MV) for 12 days. Urinary protein excreted from the $20 \mathrm{M}$-fed, nephritic control rats increased rapidly and linearly during the initial 3 days, and thereafter the high excretion rate was maintained for up to 12 days. Two low-meatprotein diets $(8.5 \mathrm{M}, 8.5 \mathrm{MV})$ commenced to suppress proteinuria 3 days after feeding and the suppression was preserved during the rest of the experimental periods. Compared with the $20 \mathrm{M}$, both low-meat-protein diets significantly improved hypercholesterolemia induced in this nephritic model. These two diets significantly enhanced the fecal excretion of neutral sterols. They caused neither fatty liver nor severe growth retardation. These effects of $8.5 \mathrm{MV}$ were identical to those of $8.5 \mathrm{M}$. The results suggest that low-meat-protein feeding, without amino acid supplementation, improves hypercholesterolemia and proteinuria in nephritis without severe protein malnutrition. The results also suggest that the hypocholesterolemic effect of the low-meat-protein diets may be, at least in part, attributed to increased fecal excretion of steroids.

Key Words hypercholesterolemia, proteinuria, nephritis, nephrotoxic serum, meat protein, low-protein diet, serum cholesterol, neutral sterol, bile acid

Renal injuries such as nephrosis are often accompanied by severe hyperlipidemia as well as marked proteinuria and hypoalbuminemia $(1,2)$. The reduction of this type of hyperlipidemia, especially hypercholesterolemia, is of particular importance, since hypercholesterolemia has been believed to aggravate further the kidney dysfunction $(3,4)$. It is well established that high protein intake enhances the hyperfiltration of glomerulus and gradually causes progressive damage $(5,6)$. 
Thus, the restriction of protein intake is so far shown to alleviate proteinuria in nephritic patients (7) and rats (8). We have reported that an 8.5\%-protein diet containing either casein, whole egg protein, soy protein, or wheat gluten, as compared with a 20\%-protein diet containing a correponding protein source, reduces hypercholesterolemia as well as proteinuria in rats with nephrotoxic serum nephritis (NSN) (9). Low-protein diets, however, induce either fatty liver or growth retardation despite their beneficial effects (9). Concurrent addition of cystine and threonine to low-casein diets is found to diminish these obstructions without loss of the reductive effects on hypercholesterolemia and proteinuria in the nephritic state (10).

In the present study, we have examined the quantitative effect of dietary swine meat protein on hypercholesterolemia and proteinuria in rats with NSN. The amino acid score of swine meat protein is considered to be $100(11)$. However, the score of loin, for instance, fluctuates depending on differences in swine strains, and the first limiting amino acid is valine when amino acid score is less than 100 (12). Valine, together with other branched-chain amino acids such as leucine and isoleucine, has been reported to increase the synthesis of plasma proteins such as albumin in cultured hepatocytes (13). Hence, the effect of supplementing a low-meat protein diet with valine on the serum albumin level has also been examined in rats with NSN.

\section{MATERIALS AND METHODS}

Animal treatment. Male Wistar rats (4 weeks of age) were obtained from Charles River Japan (Kanagawa). They were kept on a stock pellet diet (CE-2, CLEA Japan, Tokyo) for 5 days and fed on a standard diet (see below) for another 5 days in an air-conditioned room with a temperature of $22 \pm 2^{\circ} \mathrm{C}$, a relative humidity of $60 \pm 5 \%$, and a 12 -h light-dark cycle $(08: 00-20: 00)$. The animals were moved on the 7 th day of the preliminary feeding from individual cages into metabolic cages to collect urine. On the 10th day of the preliminary feeding (day 0 ), the rats (average weight of $146 \mathrm{~g}$ ) were divided into three groups with equal body weights and received a single intravenous injection in the tail vein of anti-rat kidney glomerular basement membrane (GBM) rabbit antiserum $(0.4 \mathrm{ml} / \mathrm{rat})$, which was produced by immunizing rabbits with the supernate of trypsin-digested rat GBM (14-17). The following day (day 1), the animals were subcutaneously immunized with rabbit $\gamma$-globulin $(6 \mathrm{mg} /$ rat, Sigma Chemical Co., St. Louis, MO) in $0.2 \mathrm{ml}$ of Freund's complete adjuvant (Wako Pure Chemical Industries, Osaka) into hind footpads as described previously $(14,17)$. Immediately after the antiserum injection (day 0), rats of each group were given a particular experimental diet (see below) for 12 days ad libitum.

Preparation of meat protein. The meat protein was prepared from swine loin (separable lean, purchased from a butcher shop in Fuchu, Tokyo) by the method described by Noguchi and Kim (18). The protein content determined by the 
Kjeldahl method was $92.1 \%$ in the lyophilized powder assuming that the protein factor of nitrogen is 6.25 .

Diets. The composition of the standard diet was 20\% casein (Oriental Yeast Co., Tokyo), 5\% corn oil (Hayashi Chemicals Co., Tokyo), 68.3\% $\alpha$-corn starch (Nihon Nosan Kogyo Co., Yokohama), 3.5\% mineral mixture (AIN composition, Nihon Nosan Kogyo Co.), 1\% vitamin mixture (AIN composition, Nihon Nosan Kogyo Co.), 0.2\% choline bitartrate (Wako Pure Chemical Industries), and 2\% cellulose powder (Oriental Yeast Co.). The composition of experimental diets was identical to that of the standard diet, except for protein and carbohydrate contents of low-meat-protein diets. Experimental diets were a 20\%-meat-protein diet $(20 \mathrm{M}), 8.5 \%$-meat-protein diet $(8.5 \mathrm{M})$, and $8.5 \mathrm{M}$ supplemented with $0.05 \%$ L-valine (Ajinomoto Co., Inc., Tokyo, designated as $8.5 \mathrm{MV}$ ). The composition of the $8.5 \mathrm{M}$ and $8.5 \mathrm{MV}$ was adjusted to $100 \%$ by changing the content of $\alpha$-corn starch to keep all the diets $(20 \mathrm{M}, 8.5 \mathrm{M}$, and $8.5 \mathrm{MV})$ isocaloric.

Sample collection. Urine excreted by the rats that were individually housed in metabolic cages was collected at 9:00 A.M. each day for the preceding $24 \mathrm{~h}$ as indicated in Fig. 1. Feces were collected individually for 2 days before sacrifice. The animals were deprived of their diet at 9:00 A.M. on day 12, but allowed free access to water until killing which was done $4 \mathrm{~h}$ later by decapitation. Blood was collected, left to clot at room temperature, and centrifuged to obtain serum. The liver and kidney were quickly removed, washed with cold $0.9 \% \mathrm{NaCl}$; blotted on filter paper, and weighed.

Serum albumin and urinary protein determination. The serum albumin level was determined with a commercial kit (Wako Pure Chemical Industries). Urinary protein was measured by the Bradford method (Bio-Rad Protein Assay, Bio-Rad Laboratories, Richmond, CA) (19).

Lipid analysis. Total lipids were extracted from the liver according to the procedure of Folch et al. (20), and the cholesterol (Ch) (21), triglyceride (TG) (22), and phospholipid (PL) (23) levels were determined. The serum TG and PL levels were also determined as described above. The serum $\mathrm{Ch}$ level was enzymatically determined with a commercial kit (Wako Pure Chemical Industries). The serum non esterified fatty acid (NEFA) level was measured by the method of Kushiro et al. using palmitic acid as the standard (24).

Cholesterol and fatty acid syntheses from $\left[{ }^{14} \mathrm{C}\right]$ acetate in liver slices. Liver slices weighing 100 to $120 \mathrm{mg}$ were placed in $1 \mathrm{ml}$ of Krebs-Ringer phosphate buffer (pH 7.4) containing $1 \mu \mathrm{Ci}$ of $\left[1-{ }^{14} \mathrm{C}\right]$ acetate $(1 \mathrm{mCi} / \mathrm{mmol}$, Amersham International plc, Buckinghamshire, U.K.). Total fatty acid (FA) and Ch syntheses were estimated as described previously $(25,26)$.

Fecal steroid excretion. Neutral sterol (NS) and bile acid (BA) were extracted from feces according to the procedure of Yamanaka et al. (27). NS and BA were enzymatically determined with commercial kits (Wako Pure Chemical Industries) as previously described (28).

Statistical analysis. Statistical analysis was carried out using Duncan's multi-

Vol. 40, No. 6, 1994 
ple-range test (29).

\section{RESULTS}

As seen in Table 1, body weight gain and liver and kidney weights were significantly lower in the $8.5 \mathrm{M}$ and $8.5 \mathrm{MV}$ groups than in the $20 \mathrm{M}$ group, while food intake was unchanged among the three dietary groups. The serum albumin level was not significantly changed among these dietary groups, although slight (9$12 \%$ ) but nonsignificant increases were noted in the $8.5 \mathrm{M}$ and $8.5 \mathrm{MV}$ groups in comparison with the $20 \mathrm{M}$ group. Valine supplement to the $8.5 \mathrm{M}$ did not exert any additional influence on these parameters, including the serum albumin level $(8.5 \mathrm{M}$ vs. $8.5 \mathrm{MV}$ ).

As illustrated in Fig. 1, urinary protein excretion in the 20M group rapidly and linearly increased during the initial 3 days and this high excretion rate was thereafter maintained for up to 12 days. The excretion rate of the $8.5 \mathrm{M}$ and $8.5 \mathrm{MV}$ groups commenced to decrease on day 3 as compared with the 20M group. Valine had no supplemental effect on urinary protein excretion.

The serum and liver lipid levels are shown in Table 2. The serum $\mathrm{Ch}$ level was significantly suppressed by the $8.5 \mathrm{M}$ and $8.5 \mathrm{MV}$ feeding in comparison with the $20 \mathrm{M}$ feeding. The serum TG, PL, and NEFA levels were not significantly changed among three groups, although the TG and PL levels of the $8.5 \mathrm{M}$ and $8.5 \mathrm{MV}$ groups had a tendency to decrease. Valine supplementation did not have a notable effect on the serum lipid levels. No significant alterations were observed in the liver $\mathrm{Ch}$ and TG levels among the three dietary groups. The liver PL level tended to decrease (8.5M) and significantly decreased (8.5MV) when compared with that of the $20 \mathrm{M}$ group.

Table 3 shows changes in hepatic lipid (Ch, FA) syntheses and fecal steroid

Table 1. Effects of low-meat-protein diets on body weight gain, liver and kidney weights, and serum albumin level in nephritic rats.

\begin{tabular}{lccc}
\hline \multirow{2}{*}{ Measurement } & \multicolumn{3}{c}{ Diet } \\
\cline { 2 - 4 } & $20 \mathrm{M}$ & $8.5 \mathrm{M}$ & $8.5 \mathrm{MV}$ \\
\hline Initial body weight $(\mathrm{g})$ & $146 \pm 2$ & $146 \pm 3$ & $146 \pm 4$ \\
Food intake $(\mathrm{g} / 12$ days $)$ & $226 \pm 7$ & $234 \pm 5$ & $222 \pm 15$ \\
Body weight gain $(\mathrm{g} / 12$ days $)$ & $76 \pm 2^{\mathrm{a}}$ & $53 \pm 5^{\mathrm{b}}$ & $55 \pm 9^{\mathrm{b}}$ \\
Liver weight $(\mathrm{g} / 100 \mathrm{~g}$ body weight $)$ & $5.4 \pm 0.1^{\mathrm{a}}$ & $4.7 \pm 0.2^{\mathrm{b}}$ & $4.7 \pm 0.1^{\mathrm{b}}$ \\
Kidney weight $(\mathrm{g} / 100 \mathrm{~g}$ body weight $)$ & $1.2 \pm 0.1^{\mathrm{a}}$ & $0.9 \pm 0.1^{\mathrm{b}}$ & $0.8 \pm 0.1^{\mathrm{b}}$ \\
Serum albumin $(\mathrm{g} / 100 \mathrm{ml})$ & $3.4 \pm 0.2$ & $3.7 \pm 0.1$ & $3.8 \pm 0.2$ \\
\hline
\end{tabular}

Each value represents the mean \pm standard error for seven $(20 \mathrm{M})$ or six $(8.5 \mathrm{M}$ and $8.5 \mathrm{MV}$ ) rats. 20M, 20\%-meat-protein diet; $8.5 \mathrm{M}, 8.5 \%$-meat-protein diet; $8.5 \mathrm{MV}$, $8.5 \mathrm{M}$ diet supplemented with $0.05 \% \mathrm{~L}$-valine. Values not sharing a common letter are significantly different at $p<0.05$ by Duncan's multiple-range test. 


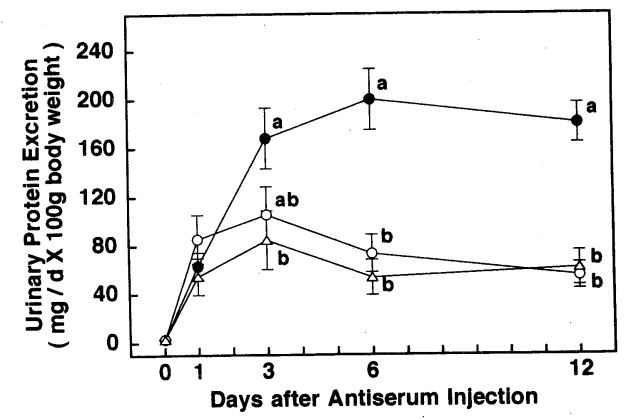

Fig. 1. Effects of low-meat-protein diets on urinary protein excretion in nephritic rats. Nephritic rats were fed on either a $20 \%$-meat-protein diet $(\bullet), 8.5 \%$ meat-protein diet $(\triangle)$, or $8.5 \%$-meat-protein diet supplemented with $0.05 \%$ L-valine $(\bigcirc)$. Each value and vertical bar represents the mean and standard error, respectively. Values not sharing a common letter are significantly different at $p<0.05$ within each indicated day by Duncan's multiple-range test.

Table 2. Effects of low-meat-protein diets on serum and liver lipid levels in nephritic rats.

\begin{tabular}{lccc}
\hline \multirow{2}{*}{ Measurement } & \multicolumn{3}{c}{ Diet } \\
\cline { 2 - 4 } & $20 \mathrm{M}$ & $8.5 \mathrm{M}$ & $8.5 \mathrm{MV}$ \\
\hline Serum lipids (mg/100 ml) & & & \\
Ch & $296 \pm 39^{\mathrm{a}}$ & $188 \pm 24^{\mathrm{b}}$ & $171 \pm 20^{\mathrm{b}}$ \\
TG & $158 \pm 38$ & $138 \pm 29$ & $107 \pm 22$ \\
PL & $329 \pm 52$ & $265 \pm 37$ & $214 \pm 20$ \\
NEFA & $553 \pm 52$ & $544 \pm 94$ & $462 \pm 59$ \\
Liver lipids (mg/g liver) $_{\text {Ch }}$ & $1.8 \pm 0.1$ & $1.8 \pm 0.2$ & $1.7 \pm 0.1$ \\
TG & $9.7 \pm 2.2$ & $7.8 \pm 0.9$ & $14.7 \pm 3.3$ \\
PL & $25.4 \pm 0.7^{\mathrm{a}}$ & $24.3 \pm 1.5^{\text {ab }}$ & $22.4 \pm 0.6^{\mathrm{b}}$ \\
\hline
\end{tabular}

Each value represents the mean \pm standard error for seven $(20 \mathrm{M})$ or six $(8.5 \mathrm{M}$ and 8.5MV) rats. Ch, cholesterol; TG, triglyceride; PL, phospholipid; NEFA, non esterified fatty acid $\left({ }^{1} \mu \mathrm{Eq} / l\right)$. Values not sharing a common letter are significantly different at $p<0.05$ by Duncan's multiple-range test.

(NS, BA) excretion. Hepatic Ch synthesis was not influenced by dietary treatment, while FA synthesis was significantly higher in the low-meat-protein groups than in the 20M group. The amount of feces and fecal NS excreted of both low-meatprotein groups was enhanced in comparison with that of the 20M group, but BA excretion was unchanged among the three groups. Valine did not show any further effect on hepatic lipid syntheses and fecal steroid excretion. 
Table 3. Effects of low-meat-protein diets on hepatic lipid syntheses and fecal steroid excretion in nephritic rats.

\begin{tabular}{lccc}
\hline & \multicolumn{3}{c}{ Diet } \\
\cline { 2 - 4 } Measurement & $20 \mathrm{M}$ & $8.5 \mathrm{M}$ & $8.5 \mathrm{MV}$ \\
\hline Hepatic lipid syntheses $\left(\mathrm{dpm} \times 10^{-4} / 2 \mathrm{~h} / \mathrm{g}\right.$ liver $)$ & & \\
Ch & $5.2 \pm 1.2$ & $7.9 \pm 1.5$ & $5.6 \pm 1.1$ \\
FA & $6.8 \pm 1.1^{\mathrm{a}}$ & $53.4 \pm 11.5^{\mathrm{b}}$ & $60.6 \pm 18.0^{\mathrm{b}}$ \\
Fecal steroid excretion $(\mu \mathrm{mol} / 2$ days $/ 100 \mathrm{~g}$ body weight $)$ & & \\
NS & $9.5 \pm 0.8^{\mathrm{a}}$ & $26.0 \pm 1.5^{\mathrm{b}}$ & $23.5 \pm 4.0^{\mathrm{b}}$ \\
BA & $4.7 \pm 0.9$ & $7.2 \pm 1.1$ & $3.8 \pm 1.2$ \\
Feces & $0.67 \pm 0.04^{\mathrm{a}}$ & $0.90 \pm 0.07^{\mathrm{b}}$ & $0.92 \pm 0.05^{\mathrm{b}}$ \\
\hline
\end{tabular}

Each value represents the mean \pm standard error for seven $(20 \mathrm{M})$ or six $(8.5 \mathrm{M}$ and $8.5 \mathrm{MV}$ ) rats. Ch, cholesterol; FA, fatty acid; NS, neutral sterol; BA, bile acid. ${ }^{1}$ Dry weight basis $(\mathrm{g} / 2$ days $/ 100 \mathrm{~g}$ body weight). Values not sharing a common letter are significantly different at $p<0.05$ by Duncan's multiple-range test.

\section{DISCUSSION}

As metabolic alterations, endogenous hyperlipidemia as well as proteinuria and hypoalbuminemia are induced in rats with NSN (10). The latter two symptoms characterize nephrotic syndrome. Growth retardation is also brought about by inducing NSN (10). Among such metabolic abnormalities in NSN, the low-meatprotein diets $(8.5 \mathrm{M}, 8.5 \mathrm{MV})$ were demonstrated to significantly reduce both hypercholesterolemia and proteinuria with neither fatty liver induction nor severe growth retardation. No growth was noted when rats with NSN were given low (8.5\%)-protein diets containing soy protein or wheat gluten (9). Thus, low-meatprotein diets seem to be more advantageous for the growth of nephritic rats than low protein diets containing those vegetable proteins. In contrast, hypoalbuminemia was not significantly alleviated by feeding the $8.5 \mathrm{M}$. The supplement of valine to $8.5 \mathrm{M}$ failed to elevate the serum albumin level in the nephritic state $(8.5 \mathrm{M}$ vs. 8.5 MV). The valine supplement, again, did not exert any further influence on the growth of rats, liver and kidney weights, urinary protein excretion, and the serum Ch level (8.5M vs. 8.5MV). A possible explanation why valine had no effect is that valine may not be a limiting amino acid of meat protein isolated in the present study, although the possibility that the amount of valine added to the $8.5 \mathrm{M}$ was insufficient can not be ruled out.

Hepatic Ch and FA syntheses in rats with NSN increase in comparison with those in normal rats, while fecal steroid excretion was unchanged between the normal and nephritic states (10). In the present study, hepatic Ch synthesis was not modulated by the dietary manipulations, while fecal excretion of NS was stimulated by feeding the low-meat-protein diets in comparison with the 20M feeding. The anti-hypercholesterolemic effect of the $8.5 \mathrm{M}$ and $8.5 \mathrm{MV}$ may therefore be, at least 
partly, due to increased excretion of NS from the body. The serum NEFA level was similar among three dietary groups, and hepatic FA synthesis was notably stimulated in the 8.5\%-meat-protein groups. However, the serum and liver TG levels were not elevated in these groups. Thus, the TG levels are assumed to be regulated by factors other than hepatic FA synthesis and FA mobilization. Such factors may include: (a) increased FA oxidation in the liver, (b) increased clearance of TG-rich lipoproteins by lipoprotein lipase (LPL), and (c) normalization of abnormal lipoprotein composition which is observed in nephrosis and retards the hydrolysis of lipoprotein-TG by LPL $(30,31)$. Further studies are needed to clarify these aspects.

In conclusion, low-meat-protein ingestion is demonstrated to improve hypercholesterolemia and proteinuria in rats with NSN without fatty liver induction and severe growth retardation, even if amino acid supplementation is not carried out. Low-meat-protein ingestion is therefore suggested to have beneficial effects on this diseased condition, like the ingestion of amino acid-fortified low casein diets (10).

This work was supported by a grant from the Ito Foundation, Tokyo, Japan.

\section{REFERENCES}

1) Gherardi, E., Rota, E., Calandra, S., Genova, R., and Tamborino, A. (1977): Relationship among the concentrations of serum lipoproteins and changes in their chemical composition in patients with untreated nephrotic syndrome. Eur. J. Clin. Invest., 7, 563-570.

2) Marsh, J. B., and Sparks, C. E. (1979): Lipoproteins in experimental nephrosis: Plasma levels and composition. Metabolism, 28, 1040-1045.

3) Moorhead, J. F., El-Nahas, M., Chan, M. K., and Varghese, Z. (1982): Lipid nephrotoxicity in chronic progressive glomerular and tubulo-interstitial disease. Lancet, 2, 1309-1312.

4) Shohat, J., and Boner, G. (1993): Role of lipids in the progression of renal disease in chronic renal failure: Evidence from animal studies and pathogenesis. Isr. J. Med. Sci., 29, 228-239.

5) Brenner, B. M., Meyer, T. W., and Hostetter, T. H. (1982): Dietary protein intake and the progressive nature of kidney disease: The role of hemodynamically mediated glomerular injury in the pathogenesis of progressive glomerular sclerosis in aging, renal ablation, and intrinsic renal disease. N. Engl. J. Med., 307, 652-659.

6) Woods, L. L. (1993): Mechanisms of renal vasodilation after protein feeding: Role of the renin-angiotensin system. Am. J. Physiol., 264, R601-R609.

7) Kaysen, G. A., Gambertoglio, J., Jimenez, I., Jones, H., and Hutchison, F. N. (1986): Effect of dietary protein intake on albumin homeostasis in nephrotic patients. Kidney Int., 29, 572-577.

8) Remuzzi, G., Zoja, C., Remuzzi, A., Rossini, M., Battaglia, C., Broggini, M., and Bertani, T. (1985): Low-protein diet prevents glomerular damage in adriamycintreated rats. Kidney Int., 28, 21-27.

9) Fujisawa, K., Yagasaki, K., Adachi, I., and Funabiki, R. (1994): Qualitative and 
quantitative effects of dietary proteins on hyperlipidemia and proteinuria in nephritic rats. Nutr. Res., 14, 1055-1066.

10) Fujisawa, K., Yagasaki, K., and Funabiki, R. (1994): Reduction of hyperlipidemia and proteinuria without growth retardation in nephritic rats by amino acids-fortified low casein diets. J. Nutr. Biochem., 5, 21-27.

11) Resources Concil, Science and Technology Agency, Japan (1986): Standard Tables of Food Composition in Japan, Amino Acid Composition of foods, revised ed., Printing Bureau, Ministry of Finance, Tokyo, pp. 312-313.

12) Zaidanhōjin Nihon Shokuniku Shōhi Sōgō Center (1992): Shokunikuseibunhyō, Kyōdō Senden Co., Ltd., Tokyo, p. 58.

13) Montoya, A., Gómez-Lechón, M. J., and Castell, J. V. (1989): Influence of branchedchain amino acid composition of culture media on the synthesis of plasma proteins by serum-free cultured rat hepatocytes. In Vitro Cell. Develop. Biol., 25, 358-364.

14) Yagasaki, K., Matsumoto, M., Fujisawa, K., Kuboya, A., and Funabiki, R. (1992): Effect of dietary lysine on endogenous hyperlipidemia in nephrotic rats. Biosci. Biotech. Biochem., 56, 980-982.

15) Shibata, S., Miyakawa, Y., Naruse, T., Nagasawa, T., and Takuma, T. (1969): A glycoprotein that induces nephrotoxic antibody: Its isolation and purification from rat glomerular basement membrane. J. Immnol., 102, 593-601.

16) Suzuki, Y., Nagamatsu, T., Kito, T., Kohmura, T., and Ito, M. (1981): Pharmacological studies on experimental nephritic rats (11). Changes in pathohistological and biochemical parameters in anti-rat GBM rabbit serum-induced nephritis. Folia Pharmacol. Japon, 77, 407-417.

17) Suzuki, Y., Tukushi, Y., Ito, M., and Nagamatsu, T. (1987): Antinephritic effect of Y19018, a thromboxane A synthetase inhibitor, on crescentic-type anti-GBM nephritis in rats. Jpn. J. Pharmacol., 45, 177-185.

18) Noguchi, T., and Kim, J. H. (1990): Preparation of purified protein and peptide mixture from meat and evaluation of their nutritional value. Final Rep. Res. Grants Meat Meat Prod., 8, 340-344.

19) Bradford, M. M. (1976): A rapid and sensitive method for the quantitation of microgram quantities of protein utilizing the principle of protein-dye binding. Anal. Biochem., 72, 248-254.

20) Folch, J., Lees, M., and Sloane-Stanley, G. H. (1957): A simple method for the isolation and purification of total lipides from animal tissues. J. Biol. Chem., 226, 497509.

21) Zak, B. (1957): Simple rapid microtechnic for serum total cholesterol. Am. J. Clin. Pathol., 27, 583-588.

22) Van Handel, E. (1961): Suggested modification of the micro determination of triglycerides. Clin. Chem., 7, 249-251.

23) Chen, P. S., Jr., Toribara, T. Y., and Warner, H. (1956): Microdetermination of phosphorus. Anal. Chem., 28, 1756-1758.

24) Kushiro, H., Takano, Y., Soyama, K., and Fukui, I. (1970): Evaluation of colorimetric serum free fatty acid determination methods: I. On the Itaya-Ui method. Jpn. J. Clin. Pathol., 18, 51-54.

25) Yagasaki, K., Okada, K., Mochizuki, T., Takagi, K., and Irikura, T., (1984): Effect of 4-(4'-chlorobenzyloxy)benzyl nicotinate (KCD-232) on triglyceride and fatty acid 
metabolism in rats. Biochem. Pharmac., 33, 3151-3163.

26) Okada, K., Yagasaki, K., Mochizuki, T., Takagi, K., and Irikura, T. (1985): Effect of 4-(4'-chlorobenzyloxy)benzyl nicotinate (KCD-232) on cholesterol metabolism in rats. Biochem. Pharmac., 34, 3361-3367.

27) Yamanaka, Y., Tsuji, K., and Ichikawa, T. (1986): Stimulation of chenodeoxycholic acid excretion in hypercholesterolemic mice by dietary taurine. J. Nutr. Sci. Vitaminol., 32, 287-296.

28) Yagasaki, K., Machida-Takehana, M., and Funabiki, R. (1990): Effects of dietary methionine and glycine on serum lipoprotein profiles and fecal steroid excretion in normal and hepatoma-bearing rats. J. Nutr. Sci. Vitaminol., 36, 45-54.

29) Duncan, D. B. (1955): Multiple range and multiple $F$ tests. Biometrics, 11, 1-42.

30) Furukawa, S., Hirano, T., Mamo, J. C. L., Nagano, S., and Takahashi, T. (1990): Catabolic defect of triglyceride is associated with abnormal very-low-density lipoprotein in experimental nephrosis. Metabolism, 39, 101-107.

31) Levy, E., Ziv, E., Bar-On, H., and Shafrir, E. (1990): Experimental nephrotic syndrome: Removal and tissue distribution of chylomicrons and very-low-density lipoproteins of normal and nephrotic origin. Biochim. Biophys. Acta, 1043, 259-266. 